\title{
Malignant Ovarian Transitional Cell Tumor
}

National Cancer Institute

\section{Source}

National Cancer Institute. Malignant Ovarian Transitional Cell Tumor. NCI Thesaurus.

Code C40089.

An invasive malignant neoplasm that arises from the ovary and is characterized by the presence of malignant epithelial cells that resemble malignant urothelial cells. It includes transitional cell carcinoma and malignant Brenner tumor. 